\title{
DOE/ID//3074-TT
}

\section{THINKING OF THE FUTURE}
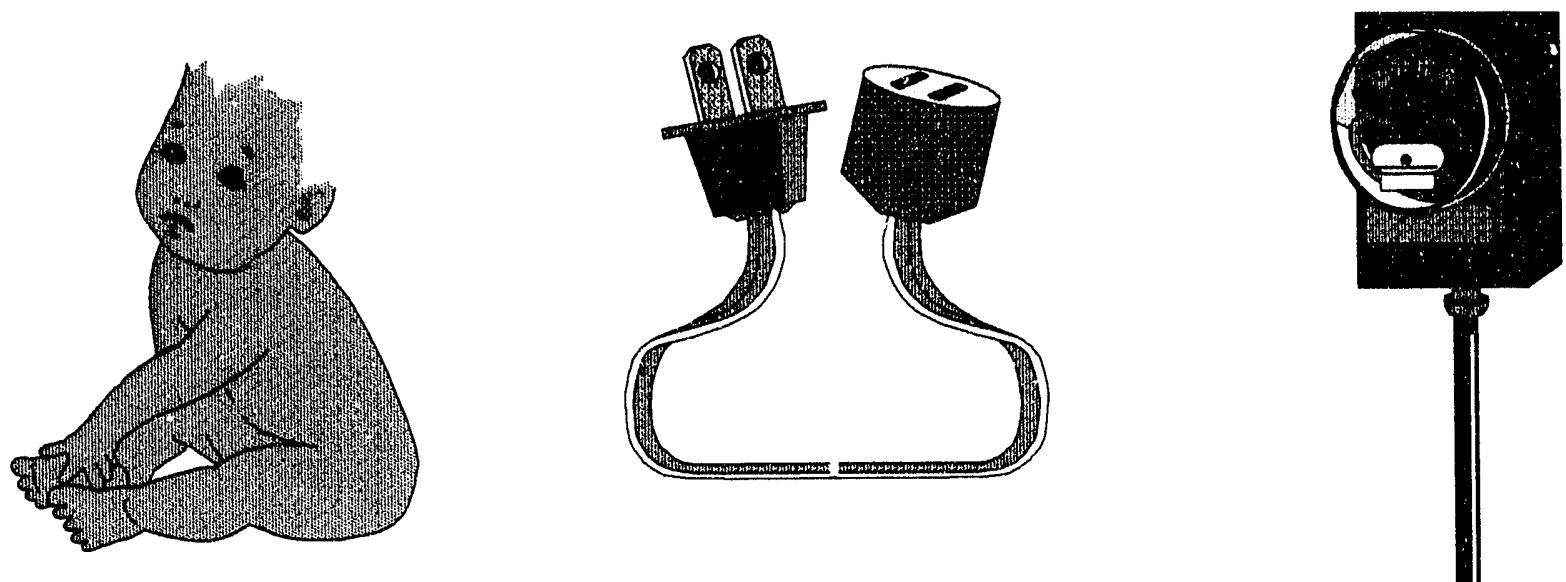

KANSAS STATE UNIVERSITY
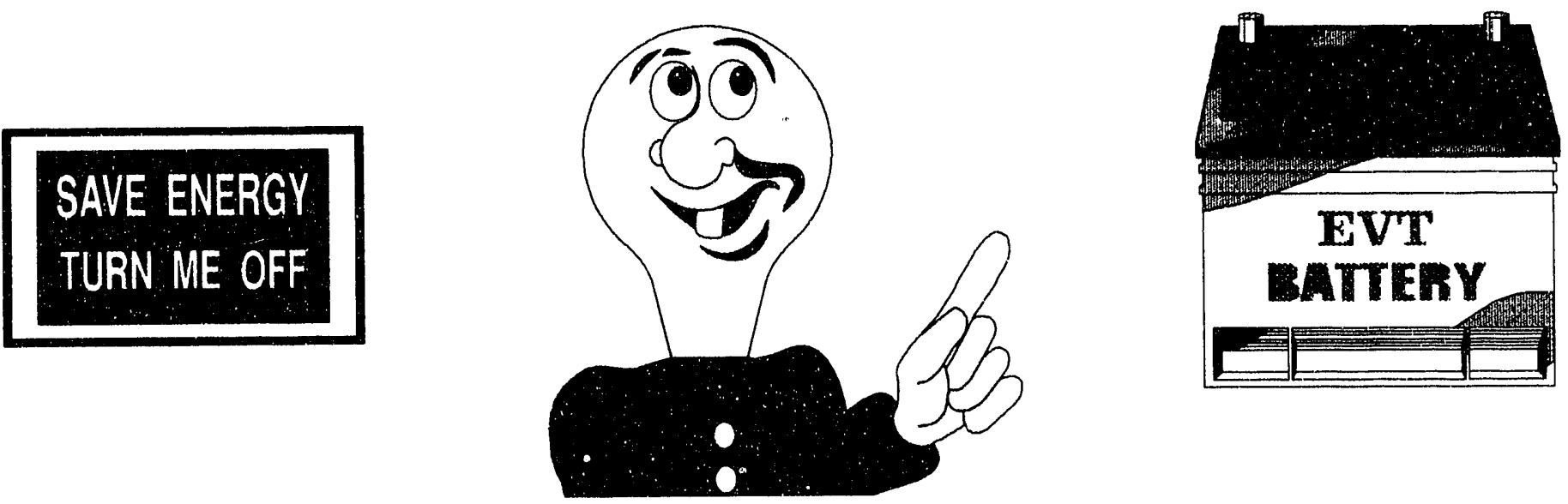

Year 2 Third Quarter Report

Jan. 1 - Mar. 311993
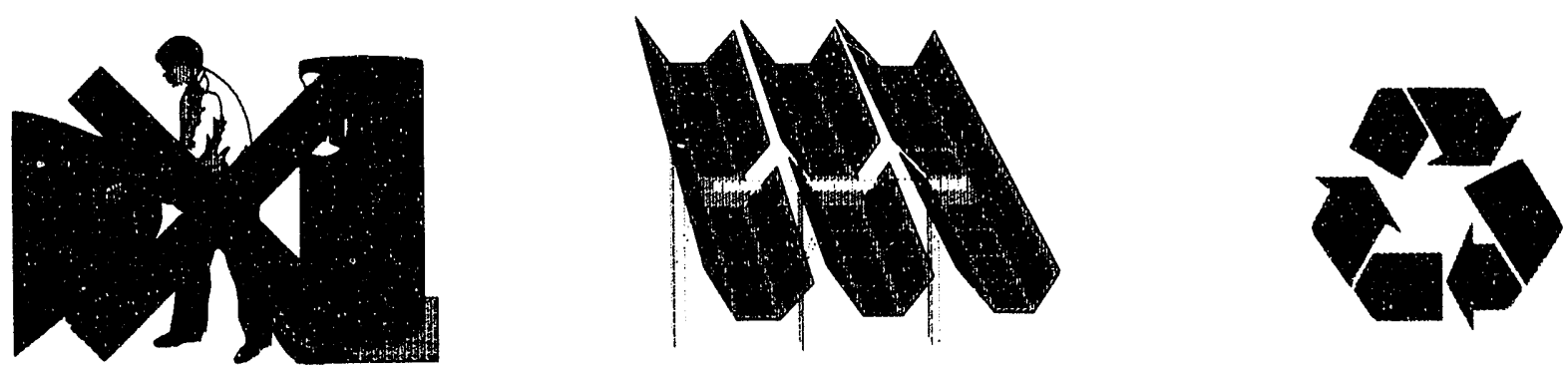

DOE/KEURP Site Operator Program

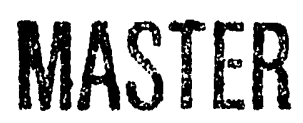




\section{DISCLAIMER}

This report was prepared as an account of work sponsored by an agency of the United States Government. Neither the United States Government nor any agency thereof, nor any of their employees, makes any warranty, express or implied, or assumes any legal liability or responsibility for the accuracy, completeness, or usefulness of any information, apparatus, product, or process disclosed, or represents that its use would not infringe privately owned rights. Reference herein to any specific commercial product, process, or service by trade name, trademark, manufacturer, or otherwise does not necessarily constitute or imply its endorsement, recommendation, or favoring by the United States Government or any agency thereof. The views and opinions of authors expressed herein do not necessarily state or reflect those of the United States Government or any agency thereof. 


\section{TABLE OF CONTENTS}

INTRODUCTION

Kansas State University . . . . . . . . . . . . . . . . . . . . . .

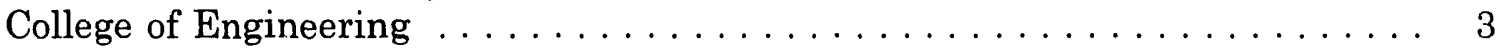

Kansas Electric Utilities Research Program .................... 3

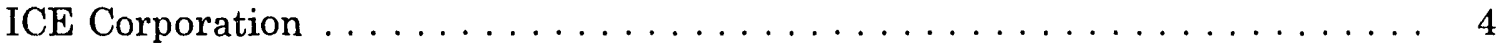

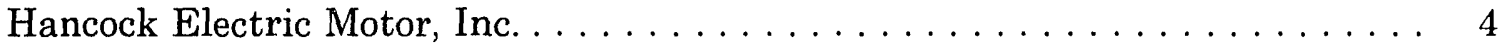

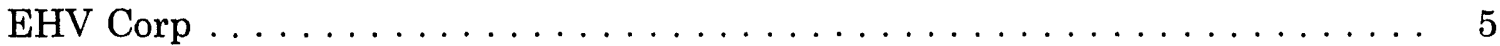

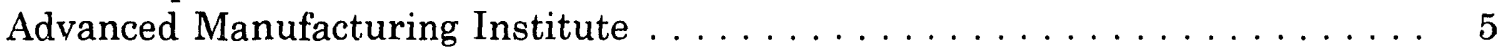

KPL, A Western Resources Company .................... 5

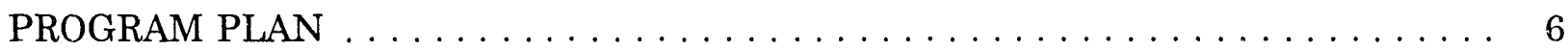

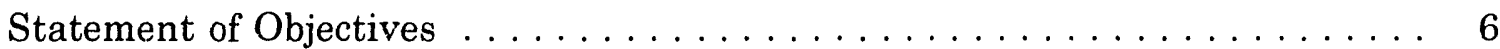

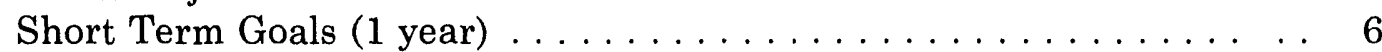

Long Term Goals $(5$ years $) \ldots \ldots \ldots \ldots \ldots \ldots \ldots \ldots \ldots$

SIGNIFICANT EVENTS/MEETINGS/FUBLICITY $\ldots \ldots \ldots \ldots \ldots \ldots \ldots \ldots$

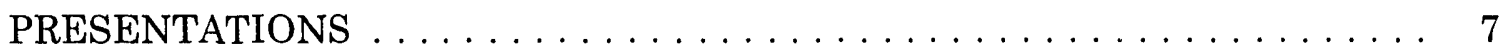

Third Quarter .......................... 7

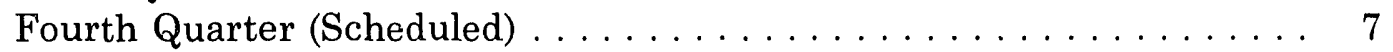

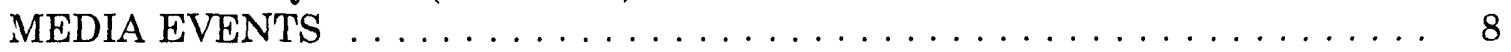

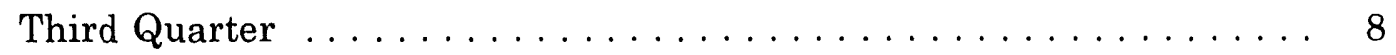

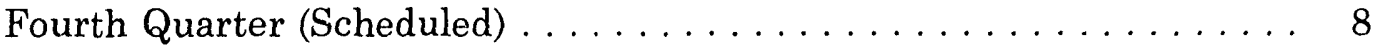

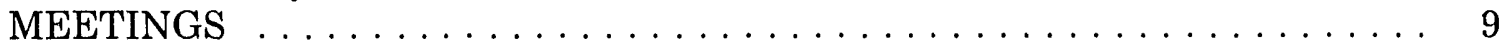

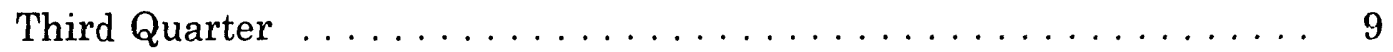

VEHICLES/COMPONENTS/BATTERIES $\ldots \ldots \ldots \ldots \ldots \ldots \ldots \ldots \ldots \ldots$

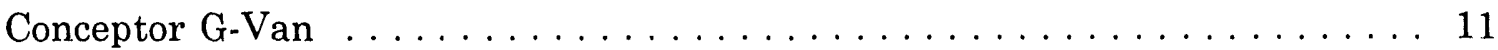

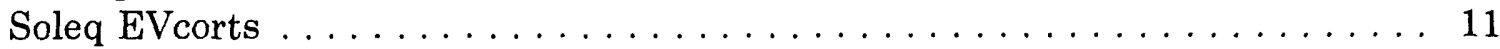

DSEP Chrysler Minivan $\ldots \ldots \ldots \ldots \ldots \ldots \ldots \ldots \ldots \ldots \ldots \ldots$

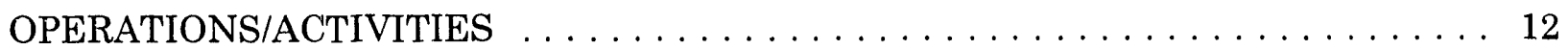

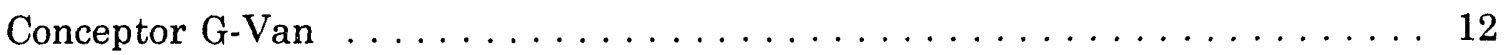

PROCUREMENT OF NEW VEHICLES $\ldots \ldots \ldots \ldots \ldots \ldots \ldots \ldots \ldots \ldots$

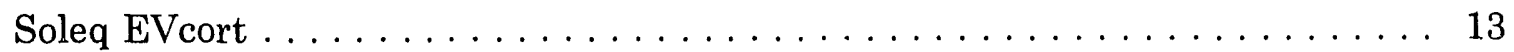

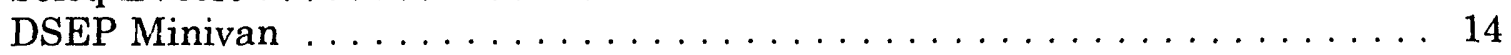

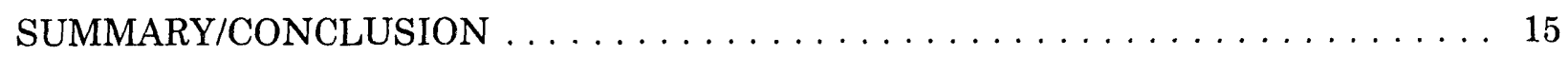

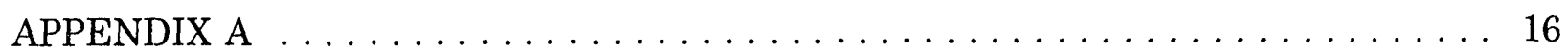

Maintenance Report .......................... 16

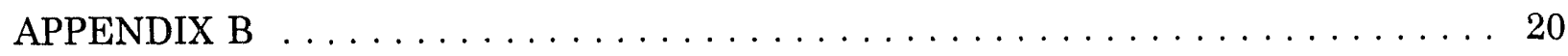

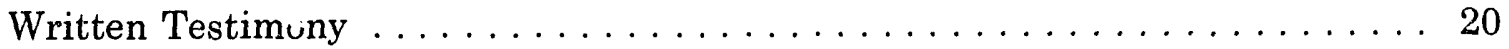

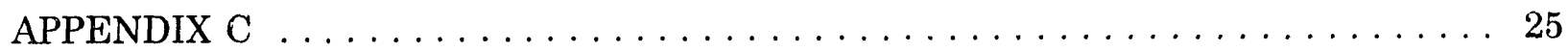

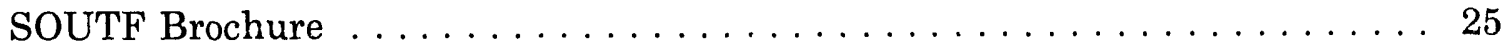




\section{INTRODUCTION}

\section{Kansas State University}

Kansas State University was founded in February 1863 as a land-grant institution under the Morrill Act. It has evolved into an internationally recognized comprehensive university that offers excellent academic programs, a lively intellectual and cultural atmosphere, and a friendly campus to its community of approximately 17,500 undergraduate and 3,500 graduate students.

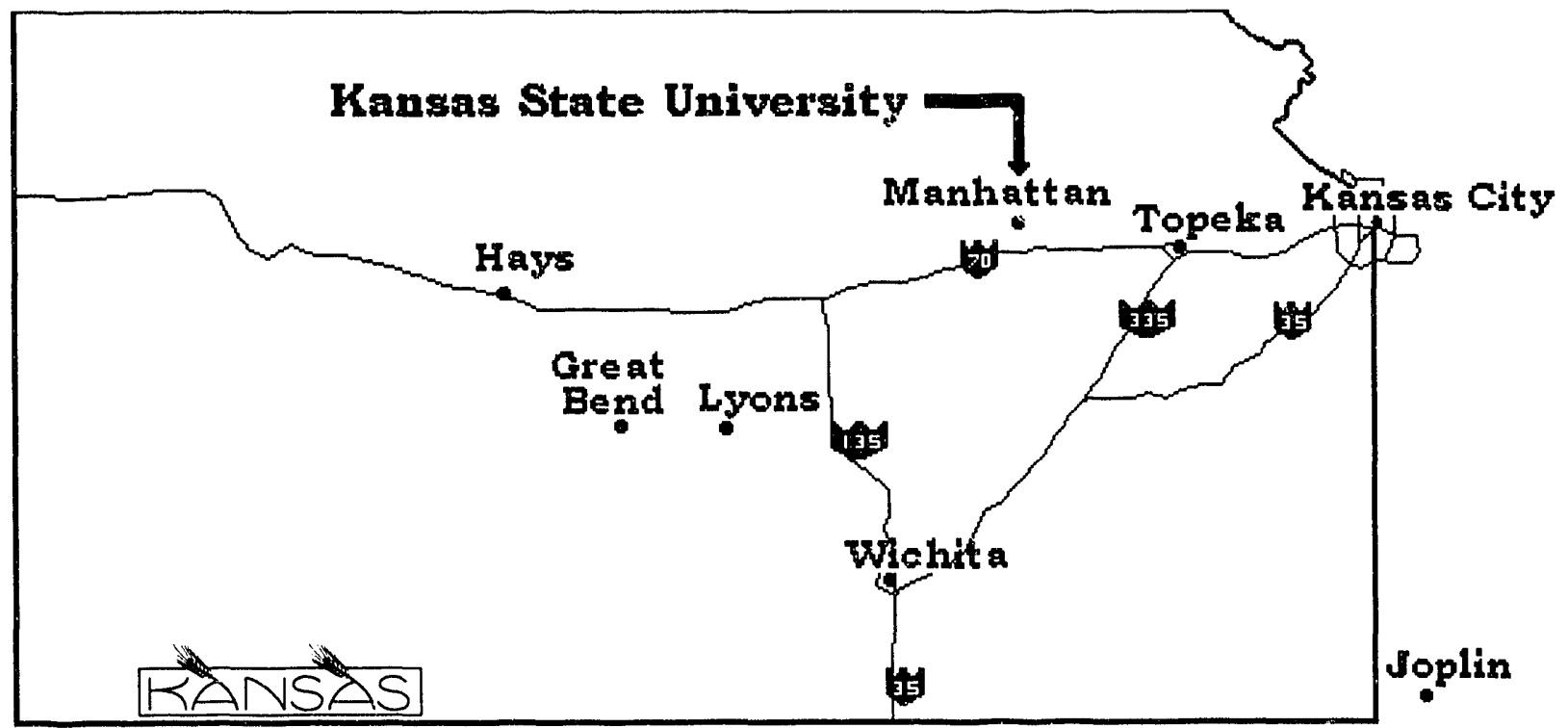

The 668-acre main campus is in the northeastern Kansas community of Manhattan. Manhattan is approximately fifty miles to the west of the state's Capital of Topeka and eighty-five miles west of Kansas City. For reference purposes, a state map is provided above. The university offers more than 200 undergraduate degree programs and options, 60 master's degree programs, and 42 doctoral programs within its eight colleges: agriculture, arts and sciences, architecture and design, business administration, education, engineering, human ecology, and veterinary medicine.

K-State accomplishments have had extensive effects: astronaut space gloves and the waterpurifying system used on the NASA space shuttles were developed here; two Kansas Centers of Excellence, one in manufacturing and one in value added research are located on campus; the University has rational hazardous substance and atomic physics research programs; the Konza Prairie Research Natural Area is used for a National Science Foundation ecological research study on erosion and prairie mammals; and a major national center for basic cancer research is at K-State.

Paul Harvey, in a special commentary, labeled Kansas State University the "student scholar 
capital of the world." This statement was made based on the number of Rhodes, Truman, Fulbright, Mellon, Goldwater, Phi Beta Kappa, Rotary International, Javits, Tilden-Snow, and Marshall scholarships that have been awarded to K-State students over the past sixteen years.

\section{College of Engineering}

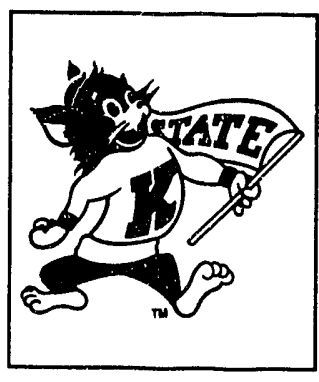

The College of Engineering at Kansas State University has excellent programs in every aspect of engineering. The college has an enrollment of 2,600 undergraduates and 300 graduate students. K-State offers degrees or options in almost every major field of engineering, including aerospace, agricultural, architectural, biomedical, chemical, civil, computer, construction sciencs, electrical, engineering technology, industrial, manufacturing, mechanical, and nuclear.

Kansas State's College of Engineering is recognized nationally for the quality of both its siudents and faculty. Approximately half of all K-State's National Merit Scholarship finalists enroll in the college.

For six consecutive years, one or more K-State students have been selected for Washington, D.C. internships in the Engineering Program. Each year WISE selects a group of only 14 to 16 engineering students from more than 200 engineering colleges across the nation to work on engineering and technology public policy issues.

Ray Dempsey, a senior in industrial engineering, was selected as the 1989-90 outstanding black engineer by the National Society of Black Engineers.

K-State's College of Engineering is one of only 10 colleges in the country to be cited twice by the National Society of Professional Engineers for its outstanding professional programs. The chapters of the departmental professional sectors have received national recognition. Most recently, agricultural engineering, civil engineering, and construction science have been designated as the outstanding student chapters in the nation.

\section{Kansas Electric Utilities Research Program}

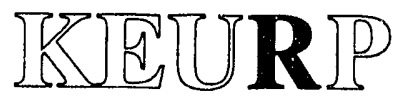

Formed on July 15, 1981, the goal of this program is to undertake applied research and development projects that may enhance reliability and minimize the cost of electric service in Kansas. The Kansas Electric Utilities Research Program (KEURP) is a contractual joint venture between six major electric utilities that serve the residents of the State of Kansas:

KPL, A Western Resources Company, Topeka, Kansas

Kansas City Power \& Light Company, Kansas City, Missouri

KG\&E, A Western Resources Company, Wichita, Kansas 
WestPlains Energy, Great Bend, Kansas

The Empire District Electric Company, Joplin, Missouri

Midwest Energy, Inc., Hays, Kansas

The establishment of KEURP was made possible by the Kansas Corporation Commission (KCC). The KCC allowed Kansas electric utilities to include research and development (R\&D) costs in their operating expenses, including dues to the Electric Power Research Institute (EPRI).

Kansas' universities play a unique role in KEURP with representation on the executive, technical and advisory committees of the program. The universities receive significant direct and indirect support from KEURP through direct funded projects as well as KEURP/EPRI co-funded projects. KEURP is working with EPRI researchers on projects to develop or expand Kansans' knowledge and expertise in the fields of high technology and economic development. KEURP is a major source of funding in the electric/hybrid vehicle demonstration program.

\section{ICE Corporation}

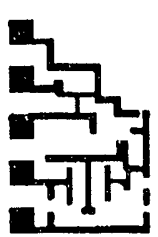

ICE Corporation is an original equipment electronics manufacturer. Seventeen employees produce solid state and microprocessor control systems for the aircraft, agriculture, and oil industries. Complete design and manufacturing facilities are located in Manhattan, Kansas.

ICE Corporation was one of seven Kansas companies that was awarded an SBIR grant from the Federal Government. The grant, from the U.S. Army Small Business Innovation Research Program for $\$ 436,000$, was earmarked to complete Phase II of ICE's research of high technology power switches. The switches may be used in anything from a computer to an automobile. These switches have ratings as high as $400 \mathrm{dc}$ volts at 100 amperes and yet are only the size of a standard business card. ICE has provided KSU with a $\$ 2,000.00$ per year written commitment in support of KSU's EHV demonstration program.

\section{Hancock Electric Motor, Inc.}

Hancock Hancock Electric Motor (HEM) is one of the largest electric motor repair faciities in the state of Kansas. The shop facilities in Lyons, Kansas, contain a welding shop (metalizing, welding, and chroming facilities), machine shop (500 ton horizontal press, 250 ton vertical press, horizontal boring machine, and a 60 inch engine lathe), dynamic balancing, vacuum pressure impregnation system, and capabilities to rewind electric motors with 13,200 volt 10,000 horsepower ratings. AC motors, DC motors, synchronous motors and generators, pumps, traction motors, locomotive main generators, alternators, generators, semihermetic motors, and haul truck wheel motors are all within the realm of HEM's repair capability. Further impedance testing can be done with the $750 \mathrm{KVA}$ core loss tester. Labor rates run $\$ 40 /$ hour with design and consulting costs at $\$ 75 /$ hour plus expenses. HEM is committed to helping KSU in EHV demonstration, research, testing, and evaluation and has provided a letter of commitment for $\$ 2,000.00$ per year for the life of DOE's 
contract. HEM has recently taken steps to allow production of electric vehicles to meet growing market demands within the Midwest region.

\section{EHV Corp}

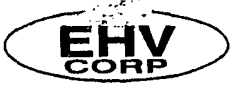

EHV Corp is a Kansas Company specializing in manufacturing infrastructure components for the electric vehicle industry. The home office of EHV Corp is located in Manhattan, Kansas. Manufacturing of electrical and mechanical parts are accomplished by other companies and EHV Corp is primarily concerned with the research and development of new products and the assembly of existing products. EHV Corp has received an economic development grant from the state of Kansas for development of its EDD-7 charging station. Further, EHV Corp has developed proposals to DOE and EPRI concerning its products. EHV Corp recently delivered its first meter for testing by a governmental laboratory. EHV Corp is hoping to establish a national demonstration program for curbside recharging within the next twelve months. This project would involve the Federal Government, Underwriters Laboratory, and major utilities in establishing curbside charging stations in major urban centers. EHV Corp has provided a letter of commitment for $\$ 10,000.00$ to establish this national demonstration program.

\section{Advanced Manufacturing Institute}

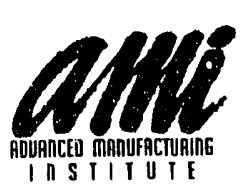

The Advanced Manufacturing Institute (AMI) was established to promote technology transfer in the state of Kansas. AMI's goal is to develop and transfer new technology to commercial manufacturers. This Center of Excellence, located in the College of Engineering, is funded by the Kansas Technology Enterprise Corporation that derives its funding through the state lottery system. AMI strives to increase economic development through research and technology transfer in advanced areas of manufacturing technology. The institute's objectives are to assist Kansas companies by working with them to expand services, design new products, and increase productivity. Special emphasis is given to the needs of smaller companies.

\section{KPL, A Western Resources Company}

Kansas Power and Light Company is part of Western Resources. Western Resources supplies electricity and natural gas to most of

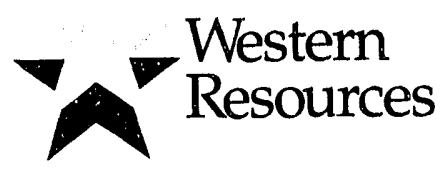
Kansas and portions of Missouri and Oklahoma. Although KPL provides funding to K-State's electric vehicle program through its membership in KEURP, it provides additional funding directly to $\mathrm{K}$ State in support of electric vehicle programs. KPL has been involved with $\mathrm{K}$-State during the last fifteen years in providing support for electric vehicles. KPL engineers are working with K-State to develop a national demonstration program to evaluate infrastructure technology for electric vehicles. 


\section{PROGRAM PLAN Statement of Objectives}

\section{Short Term Goals (1 year)}

1. Participate in the Department of Energy's Site Operator Program.

2. Evaluate Electric/Hybrid Vehicle technology through purchase of vehicles.

3. Collect user data and develop historical perspective on vehicle requirements.

4. Provide reports to DOE and KEURP on EHV data collected.

\section{Long Term Goals (5 years)}

1. Assist the nation in reversing environmental trends concerning air quality.

2. Assist Kansas City in reducing air pollution.

3. Apply and develop technological enhancements to EHVs.

4. Assist Kansas-based companies in developing EHV subsystem components for commercial use.

Kansas State University, with funding support from federal, state, public, and private companies, is participating in the Department of Energy's Electric Vehicle Site Operator Program. Through participation in this program, Kansas State is displaying, testing, and evaluating electric or hybrid vehicle technology. This participation will provide organizations the opportunity to examine the latest EHV prototypes under actual operating conditions. KSU proposes to purchase one (1) electric or hybrid vans and two (2) electric cars during the first two years of this five-year program. KSU has purchased one G-Van built by Conceptor Industries, Toronto, Canada and has initiated a procurement order to purchase two (2) Soleq 1993 Ford EVcort station wagons.

The G-Van has been signed in order for the public to be aware that this is an electric drive vehicle. Financial participants' names have been stenciled on the back door of the van. This vehicle is available for short term loan to interested utilities and companies. When other vehicles are obtained, the G-Van will be maintained on K-State's campus. 


\section{SIGNIFICANT EVENTS/MEETINGS/PUBLICITY}

\section{PRESENTATIONS}

\section{Third Quarter}

January 8

February 6

April 2-3

April 20

April 29
Advanced Manufacturing Institute Conference

Manhattan $K S$ All day conference sponsored by the Advanced Manufacturing Institute (AMI) highlighting major research activities supported by AMI. The DOE electric vehicle program presented the past years activities during a slide show and predicted future activities for the program.

Prospective Kansas State Students

Manhattan KS Professor Hague made a presentation to prospective engineering students during a recruiting day held at Kansas State University. Parents and students were shown a slide presentation about electric vehicle activities and the DOE site operator program.

\section{Fourth Quarter (Scheduled)}

Kansas State University Open House

Manhattan $K S$ The G-Van was on display during the all University Open House activities. These activities are open to the public. Parents, students, prospective students, and high school students attend this annual event displaying what K-State students are involved in and studying. The G-Van led the Engineering parade. The G-Van was also used as transportation for the King and Queen candidates.

Edison Electric Institute

Washington D.C. Professor Hague briefed the Edison Electric Institute and members on the activities of the Department of Energy's Site Operator Users Task force. Professor Hague's presentation followed a presentation by $\mathrm{Mr}$. John Brogan, Office of Transportation Technologies at DOE.

Wamego Sixth Grade Gifted Class

Wamego $K S$ The G-Van was demonstrated to members of the Wamego sixth grade gifted class. This presentation was part of a series of studies on electric motors for the class. 
May 15

June 11-12

MEDIA EVENTS

Professor Hague is scheduled to deliver two presentations on electric vehicle applications and infrastructure.

February 15

Russian General-Colonel of Russian Federation

Manhattan KS Russia's General-Colonel Vladimir M. Semenov CINC of Ground Forces Russian Federation recently paid a visit to Kansas State University. The General and Mrs. Semenov were given a tour of the K-State campus and research activities by Jon Wefald, President of Kansas State University. As part of the visit the General and his wife were scheduled for a ride in the electric G-Van.

March 3-5

APS Solar \& Electric 500

Phoenix $A R$ Members of the Site Operator Users Task Force maintained a tent displaying each site's activities for the past year. The members were available to answer questions to the general public during the past year. EHV Corp, of Manhattan, provided ten EDD-7 charging stations for infrastructure support during the race.

\section{Fourth Quarter (Scheduled)}

May 11-12

National Ride \& Drive

Washington D.C. This event is being sponsored by the Site Operator Users Task Force. The event is intended as a hands-on opportunity for Congressman, administration officials, and senior policy makers to become better acquainted with electric vehicle technology. It also provides an opportunity for Site Operator program to demonstrate a national perspective and cooperation accomplished through the Department of Energy's projects.

June 11-12 An annual event sponsored by the Kansas Corporation Commission to heighten the publics awareness about alternate fuel technology. The 1993 Soleq EVcort, 1991 G-Van, and the 1987 DSEP minivan are scheduled to 
be on public display. Also, Western Resources has worked with Arizona Public Service to have the dual battery Saturn race car on display at this event.

\section{MEETINGS}

\section{Third Quarter}

January 28

Meeting with Senator Dole's Representative

Washington D.C. Mr. Wade Graves, Western Resources and Professor Jim Hague, met with Mr. Dan Stanley, Senator Doles Administrative Assistant to discuss electric vehicle programs in Kansas. The Department of Energy's five year contract with Kansas State University and the Kansas Electric Utilities Research Program was the main topic of discussion.

March 5-8

Solar Electric 500

Phoenix $A Z$

The second quarter Site Operator Users Task Force (SOUTF) meeting was held in Phoenix Arizona in conjunction with the APS Solar and Electric 500. A joint session was held with the G-Van Users Group. EPRI wanted to take this opportunity to brief all members on Lyntech's involvement with G-Van support and warranty maintenance work.

March 30

Testimony before House Subcommittee

Washington D.C. Professor Hague presented written and oral testimony to the Subcommittee on Interior and Related Agencies Committee on Appropriations of the United States House of Representatives (see Appendix B). This testimony was provided in support of the Site Operator Users Task Force. Additional funding of $\$ 3.8$ million was requested to meet the fiscal year 1994 goals.

\section{Fourth Quarter (Scheduled)}

April 6-7

Department of Energy Offivials

Washington D.C. Professor Hague and Mr. Brad Johnson met with Mr. Tom Gross, Associate Deputy Assistant Secretary for the Office of Transportation Technologies at the Department of Energy to discuss the future of the Site Operator Users Task Force program.

April 19-20

Department of Energy - Five Year Plan

Washington D.C. A meeting was held to develop a five year plan to incorporate basic and 
applied research at the Department of Energy. This program was developed in an effort to meet congressional requests that more synergism be accomplished between basic theoretical research and applied research. The belief is this will make America more competitive in a global market place.

April 28-30

Testimony to Senate

Washington D.C. Professor Hague presented written testimony to the Senate Interior Appropriations Subcommittee of the United States Senate concerning the Site Operator Users Task Force. A brief explanation of Site activities was pruvided along with a request to increase funding for the Site Operator Program by $\$ 3.8$ million. 


\section{VEHICLES/COMPONENTS/BATTERIES}

\section{Conceptor G-Van}

Kansas State University's G-Van, VIN 29CGG35X1MN103048, was purchased in August 1991. The G-Van will be referred to by the Department of Energy's electric vehicle ID number 150 on all the mainterınce reports.

Routine maintenance was performed on the G-Van by Hancock Electric Motors, located in Lyons, Kansas (see Appendix A). This work was accomplish in March with two objectives in mind. Assist a small Kansas Company in becoming more proficient in electric vehicle technology and perform required maintenance on the G-Van. Routine maintenance included replacement of the motor cooling air filter. four new flame arresters, and removal and inspection of the battery pack, and removal, disassernbly, and inspection of the drive motor. The range of the $G-V a n$ continues to diminish. During the third quarter range is limited to 20 to 25 miles per charge while the efficiency has dropped off to $1.48 \mathrm{kwh} / \mathrm{mile}$. It is expected that the batteries or motor will fail before the end of summer 1993. Hancock Electric contacted both Lyntech and EPRI, copies of letters are included as appendix A, but no satisfactory solution was reached as to how repair of existing G.Vans can be accomplished.

\section{Soleq EVcorts}

The two Soleq EVcorts were officially ordered in April 1992. Receipt of one 1993 Soleq vehicle is officially expected to be received not later that May 15, 1993. The second vehicle is expected to be delivered by late July 1993. The first EVcort, VIN 1FAPP15JXPW125411, will be referred to by the Department of Energy's electric vehicle ID number 151, and the second EVcort, VIN 3FAPP15J9PR106495, will be referred to by the Department of Energy's electric vehicle ID number 152 on all the maintenance reports.

\section{DSEP Chrysler Minivan}

Kansas State University submitted a proposal to the U.S. Department of Energy in response to an RFP. The purpose of K-State's proposal was to obtain an experimental electric vehicle designed around a Chrysler minivan. The dial shaft electric propulsion (DSEP) minivan was built under contract by Eaton Corporation in 1987. The DSEP had been on loan to Los Angeles Department of Water and Pow until the battery system failed. Based on the acceptance of KState's proposal, an engineer was sent to inspect the DSEP vehicle. The inspection and report have been completed. Shipping arrangements were made by EG\&G Idaho Laboratory to have the vehicle delivered to Manhattan, Kansas. The DSEP vehicle arrived in Manhattan in early February. The minivan's VIN is $187 \mathrm{GK} 14 \mathrm{~K} 0 \mathrm{HX} 100100$ and will be referred to by the Department of Energy's electric vehicle ID number 153 on all future maintenance reports. 


\section{OPERATIONS/ACTIVITIES}

\section{Conceptor G-Van}

The Conceptor G-Van, DOE number 150, has been operated regularly since its procurement in August 1991. Tine van is used primarily as a demonstration vehicle. It is also used for errands for the K-State's Site Operator Project and for the Engineering Technology Department. The vehicle is used in normal everyday driving conditions around Manhattan, KS. The G-Van has been operated in various types of weather and driving conditions.

The G-Van is routinely charged indoors in a temperature controlled environment. The ambient charging temperature for this vehicle is 70 to 80 degrees Fahrenheit. The vehicle is occasionally charged in other less controlled environments as it is being demonstrated around the state. During demonstrations and shows the vehicle is not driven extensively, instead it serves as a static dispiay. Valuable data does not exist during these demonstration periods, therefore charging conditions cannot be evaluated. Table 1 gives a general review of the data collected on the Conceptor G-Van operated during this reporting period.

\begin{tabular}{|c|c|c|c|c|c|c|c|}
\hline & DATE & MLES & DAILY & $\begin{array}{l}\text { NUMBER OF } \\
\text { CHARGES }\end{array}$ & $\begin{array}{c}\text { MILES } \\
\text { PER CHARGES }\end{array}$ & $\begin{array}{l}\text { KWH } \\
\text { USED }\end{array}$ & $\begin{array}{l}\text { KWH PER } \\
\text { MILE }\end{array}$ \\
\hline Tst Quarter & $09 / 30 / 92$ & 1924.0 & 20.91 & 64 & 30.06 & 2314 & 1.20 \\
\hline 2nd Quarter & $12 / 31 / 92$ & 1109.6 & 12.06 & 7 & 15.63 & 1384 & 1.25 \\
\hline उrdQuarter & $03 / 31 / 93$ & T027.3 & 11.17 & 60 & 17.12 & 1516 & 1.48 \\
\hline 4ic Quarter & $06 / 30 / 93$ & & & & & & \\
\hline TOTAL & TODATE & 11063.8 & 18.66 & 405 & 27.32 & 13521 & 1.22 \\
\hline
\end{tabular}

TABLE 1. G-VAN (150) OPERATION SUMMARY

Assuming a price of $\$ .05 / \mathrm{kWh}$ for electricity, and $16 \mathrm{mpg}$ for the internal combustion engine GMC Vandura, the cost of operating the G-Van on electricity equates to $\$ 1.18$ per gallon of gasoline. 


\section{PROCUREMENT OF NEW VEHICLES}

\section{Soleq EVcort}

Procurement of two Soleq (Ford) EVcort wagons has been initiated by Kansas State University in April, 1992. 'The cost for both Soleq vehicles totaled $\$ 116,330$. K-State's budget included $\$ 105,000$ for these vehicles. KEURP and DOE were contacted with a request to increase funding $\$ 11,330$. KEURP and DOE have provided written commitment to fund the additional money required for the purchase of these vehicles and ancillary equipment. The 1993 Ford station wagons (gliders) have been purchased and received by Soleq. The vehicles are now being converted to electric. Although no official delivery date has been provided by the manufacturer, both vehicles are expected to be on campus not later than July, 1993. Advance payment of $\$ 56,000$ was made to Soleq Corporation to cover the cost of "mule" purchase and major components required to assemble the vehicles.

It is expected that one EVcort will be operated on and around K-State's campus. It will remain in the possession of the university with the option to be lent to interested organizations for short durations. The second EVcort is expected to be delivered to the Kansas Electric Utilities Research Program (KEURP) in Topeka, Kansas. The vehicle will be owned by K-State but, will be on long term loan to KEURP. KEURP plans to use the vehicle for demonstration purposes. K-State will receive all data from daily use of these vehicles. All data collected on K-State's vehicles will include standard information required by contract with DOE.

Topeka is the capital of Kansas. KEURP's EVcort will be immersed in the state's political arena. The EVcort is expected to demonstrate an alternative to the state's recent decision to convert large numbers of state vehicles to natural gas. This announcement, made by Governor Finney, has caused many companies to focus specifically on natural gas as "the" alternate fuel system. Having a quality electric vehicle in Topeka will allow senior government officials the opportunity to realize that other alternatives to natural gas exist for Kansas. Further, Kansas must recognize that converting from gasoline to natural gas is only a short-term temporary environmental solution. It must be recognized we are still operating with the same inefficient internal combustion engine and one fossil fuel (petroleum) has been traded for another fossil fuel (natural gas). Both fuels are limited in quantity. Further our nation's home heating system depends on the availability of natural gas. Are we creating a future crisis by switching large numbers of our transportation system to natural gas? Only time will answer that question.

The 1993 Ford EVcorts produced by Soleq will contain the latest state-of-the-art electric vehicle technology. From the latest user-selectable controller, to electronic amenities, these vehicles will demonstrate advanced technology. Operator acceptance is a major concern for electric vehicles, considering the fact that initial estimates show that EVs will cost more than their internal combustion counterparts. Soleq's EVcort should provide $\mathrm{K}$-State and Kansas with an excellent demonstration vehicle. 


\section{DSEP Minivan}

Procurement of the DSEP Minivan built by Eaton for the U.S. Department of Energy will take place at the end of January 1993. Thu vehicle is being donated to Kansas State University Site Operator Program as part of the Department of Energy's ERLE program.

Presently the vehicle is in need of a new battery pack and repairs to its DC-DC controller. The original batteries were nickel-iron batteries produced by Eagle Picher Corporation in Joplin, Missouri. Discussion has begun with Eagle Picher to obtain a new set of nickel-iron batteries. All electronic repairs will be contracted with local firms. 


\section{SUMMARY/CONCLUSION}

This has been a very busy quarter. Serving as Chairman has provided both challenges and opportunity. Much of Professor Hague's time has been spent coordinating Site Operator User Task Force information and data with senior DOE Officials and Congressional Staff. If the SOUTF is to be an effective part of DOE's long term plans, it is imperative that increased funding be obtained. This Federal funding demonstrates the Congressional commitment to see the electric vehicle transportation alternative grow. It demonstrates to the utilities and cities across this nation that the Federal Government is a serious participant in this transportation technology. The importance of this activity cannot be overstated. The long term success of this program requires considerable coordination. It is imperative that the Chairman be knowledgeable in meeting the needs of not only the task force members but Congressional Staff and senior DOE Officials. Hopefully, the groundwork accomplished during the past quarter is a good start toward obtaining additional funding for this nationally important program.

During this quarter a number of major events were undertaken by the Site Operator members. A brochure highlighting the activities of each member and their location was produced for distribution (see Appendix C). Because of the interest in the first printing, a second printing was executed. The brochure serves as a marvelous example of a costeffective product which highlights a successful Department of Energy program.

The annual APS Solar \& Electric 500 was held this year. The highlight may well have been the fact that an electric car set a speed record at the Phoenix International racetrack of a little over 100 miles per hour. The Site Operators held their meeting during this event and participated in the sponsorship of the Ernie Holden promoted race. Further, the Site Operators volunteered shifts to work the Department of Energy's tent. A large display, demonstrating the DOE Site Operator Program activities was available for public view. Questions were answered during the two day event.

The National Ride \& Drive, planned for Washington, D.C. is being planned with Brad Johnson. Professor Hague participated in this event last year. The expected participation has increased dramatically in just one year. Over fifteen vehicles are anticipated with major static displays expected by a large number of corporations and cities. Planning will continue early into the next quarter before this event is finally held.

The K-State DSEP vehicle was received in good condition. Initial planning has begun on how to make this electric vehicle an effective part of the Site Operator Program here at K-State. The vehicle will be on display in June at the States second annual alternate fuels conference to be held in Topeka. The G-Van and Soleq vehicle will be used in a ride and drive demonstration. Site Operator brochures will be provided to the public and EHV Corp's charging station will be on display and demonstrated as part of the electric vehicle activities. 


\section{APPENDIX A}

Maintenance Report 
May 17, 1993

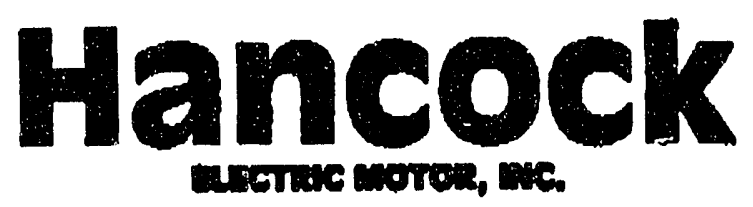

Associate Professor James R. Hague

Engineering Technology Dept.

Kansas State Universily

219 Scaton Hall

Manhattan, KS 66506

\section{Dear Professor Hague;}

During the March maintenance of your electric G-Van, performed by HEM, the veluicle traction motor has rcmoved and inspected. It was found that the coupling end portion of both the armanure and the field windings are showing signs of overheating. After finding these signs of damage we pursued the G-Van motor problcms, and this effort lead to the attached letter that was sent to Mr. Gary Purcell.

To inform you better as to the nature of the problen found in other G-Van mocors, the carastrophic failures have been reported to me as having two distinct failure locations. These fallures occur either in the commutator itaclf or between the cominutator and the armature lamination. All of these failure seem to be causcd by motor overheating due to the motors inabllity to meet the material temperature requirements. I was unablo to find any information to indicate that the signs of ovccheating present in your motor is a preliminary sign of the failures occurring on the commutator end of the motor which is opposite the coupling end. I can say that if you experience one of the fallures that har occusred in at least $\mathbf{4 0}$ other G-Vans either the winding or the commutator or both will be destroyed.

There is several problems with the G-Van motor that limits its ability to cool itself properly. One is the location of the temperature sensor in the motor. The sensor is located in the best cooled portion of the motor. This limits the sensors abllity to give an accurate feeclback of the winding temperature to control the cooling fan. This along with the fact that when the motor armature is varnished there are no air gaps remaining betwcen the commutator and the armature lamination to allow this portion of the motor to ventilate. This leaves the motor unprotected from the types of failures that are being experienced.

Mr. Purcell's response to our proposal was that at that time EPRI was interested in newer technolngy and did not desire to invest any more EPRI money into the G-Van project than necessary. I was also informed that all of the previous motor fallures were returned to England for study, but now the company is out of business. Without a few of the catastrophic failures to investigate it will be difficult to guarancy a solution to the problem. There are several possible modifications that could be made to the motor to reduce the risk of one of the catastrophic fallures. One would be to rewind the motor with a higher temperature rated insulation, HEM could modify the armature to circulate air to the portions of the motor most susceptible to the high temperatures, or we could reorient the airflow and the temperature sensor so that the sensor gives a more accurate assessment of winding temperature. Each of these procedures should be preceded and followed by a documented investigation of the motors operating conditions.

If you require any more specifics in regard to the motor or the possible solutions to the problem please contact Myron or Myself.

Sincerely,

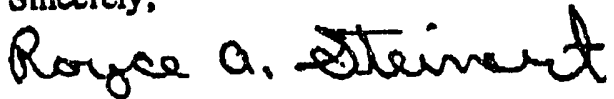

Royce A. Steinert

Project Engineer

Hancock Electric Motor, inc. • P.0. Box 668, Lyons, KS 87554-0668 • 316-257-2348 • FAX 257-2340

An Equal Opportunity Employer 


\section{Hancock}

March 19, 1993

Gary Puicoll

EPRI Transportation Program Project Manager

3412 Hillview Ave.

P.O. Box 10412

Palo Alto, CA 94303

Dear Mr. Purcell;

In a recent conversation with William Craven concerning the electric G-Van project I found that several of the G-Vans have suffered traction motor fallures. Hancock Electric Motor Inc. (HEM) is very interested in these motor failures for two reasons. First we perform the maintenance on the electric GVan owned by Kansas State University, and we have discovered that the traction motor in this vehicle is beginning to show sigins of heat damage. HEM's second interest in these motor failures is in the potential to develop an agreement with EPRI to determine the cause of the motor failures, and modify the existing motor to meet the demands of the vehicle.

HEM's prinzary function is to remanufacture, repair, and redesign $\Lambda C$ and DC motors, generators, and controls. We currently work on equipment ranging from fractional to 10,000 horsepower with voltages ranging froin 110 to 13,800 volts. With over 50 years of electric motor repair experience the HEM work force is dedicated to high quality work, and the engineoring staff is focused on finding solutions to electric motor problems. $34 \%$ of HEM's annual business is redesigning problem equipment to the customers requirements and specifications.

After further discussions of the motor failures with Mr. Frank Fontana of Con. Ed. HEM is interested in submitting a proposal to EPRI to study the G-Van traction motor and the motor's operating environment to determine the cause of the motor failures. HEM would then proceed with correcting the problems in the existing motors. Initially the proposal would request BPRI to provide HEM an electric G-Van with an operational drive system, and five failed motors to be evaluated. HEM would guarantee EPRI the return of the vehicle and three modified motors for EPRI's cvaluation. The cost of this initial proposal is projected to be approximately $\$ 63,500$. HEM would then propose to modify all of the failed G-Van traction motors, and build new motors as the program requires.

Please contact me wilh information on BPRI's intentions concerning the G-Van program. If there is a possibility of EPRI proceeding with an evaluation of the traction motor's failure problems HEM would like to have the opportunity to perform the work.

Sincerely,

Royce A. Steinert

Project Engineer

Hancook Electrlc Molor, Inc. • P.O. Box 668, Lyons, KS 67554-0668 • 316.257-2346 • FAX 257.2340 An Equal Opportunity Employer 
Submitted tos Profebaor James R. Hegue
Submitted by: Royce A. Steinert $\mathrm{OQd}$

Date: Hay 18, 1993

Th1s 1s an attachment to the eervice letter previously cent to you in regard to the G-Van routine maintenanos.

In reference to the routine G-Van mesntenunoe $I$ persormed ald 1 tome In ecoordanoe ith the 12,000 w110 neintenanos with the exoption of the cherger plug and zocket lubriation. To preform this Iinel procedure you need to put thin oogting of petxoleum jeliy an the cherger plug pooket. Thi ulil help the cocket ingert into the van receptacle ereier.

The remeinder af the 12,000 w120 maintenenae elheoke are 11mted on page OB-2 in the Conoeptor Ind. Serviee Nenupl, oop ox which $1 \mathrm{~s}$ atteohed. Tho eir Inteke Filter and the four $\mathrm{x}$ leme arreet devices vere roplaced. All wotor bruphes were inepeated for brush wear and found to have coneldereble life expectancy in the PB/PB and the AC motora. The traction motor brumhe oll were in an acoptable range of appraximotely 29 on.

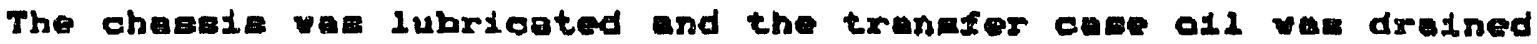
and replaced. The PB/PB and AC cantrol boxes were elpo inmpocted and the oonteotors are mowing no visible algne of arcing or weer. 


\section{MAINTENANCE SCHEDULE}

Use the chat below for scheduled maintenance services. The liem numbers in this schedule refer to the section: 'Explanatlon of Scheduled Mainienance Services'.

12

SCHEDULED MAINTENANCE SEAVICES FOR THE ELECTRIC G - VAN

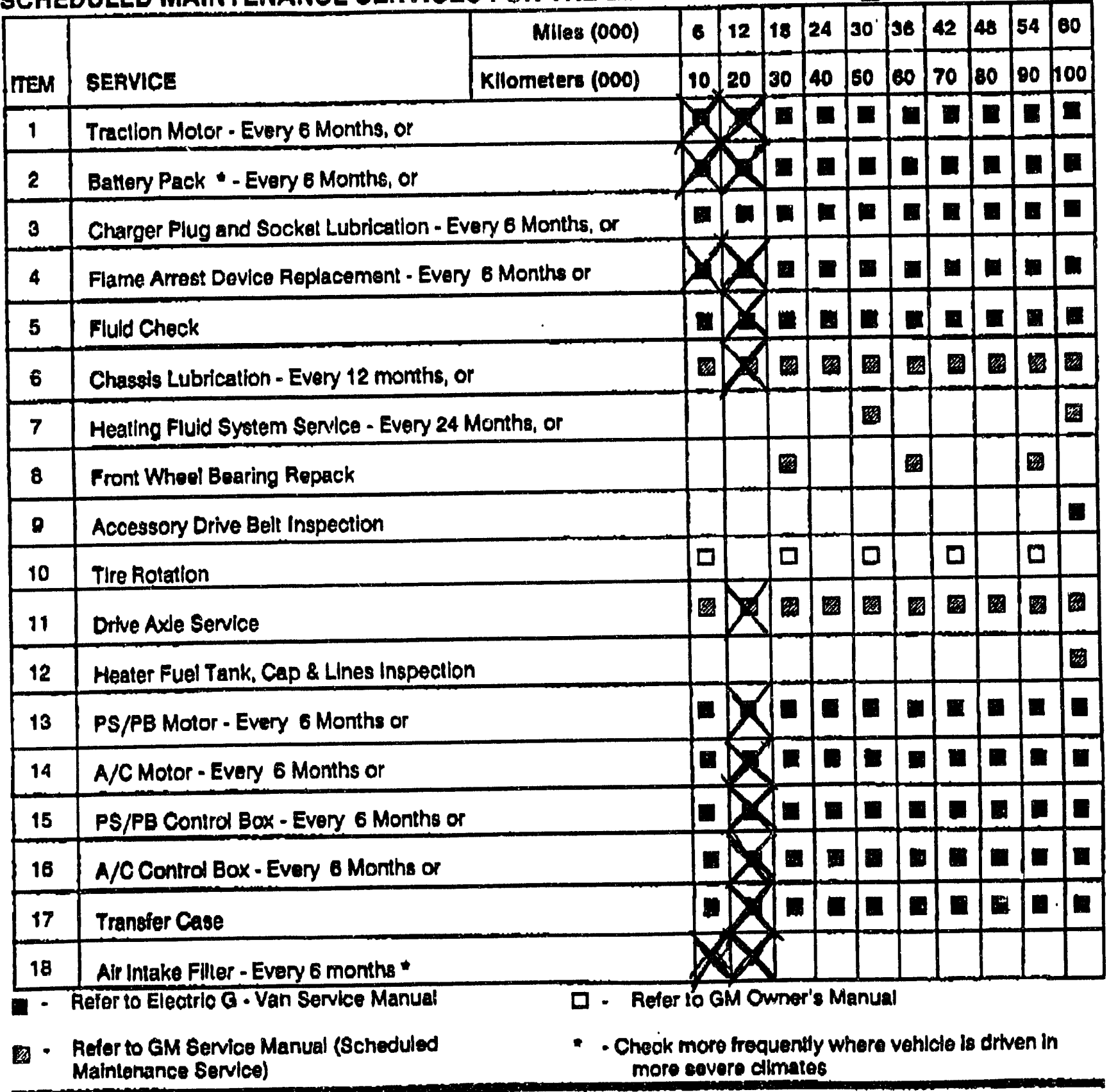


APPENDIX B

Written Testimony

20 


\section{Statement Submitted by the \\ Site Operator Users Task Force \\ to the \\ Subcommittee on Interior and Related Agencies \\ Committee on Appropriations \\ U.S. House of Representatives}

\section{March 30, 1993}

This statement is submitted for the Site Operator Users Task Force (SOUTF). The Task Force has thirteen sites (see attached map) that contractually cost-share with the Department of Energy to foster commercialization of electric transportation technologies. Commercialization is accomplished through demonstration, test, evaluation, and technology development activities. The Task Force membership has driven electric vehicles more than one million miles and employs personnel that collectively have over one hundred years of electric and hybrid vehicle operating experience. A truly unique national coalition, the SOUTF membership represents government agencies, utilities, and universities interested in promoting the use of electricity as a transportation fuel. The Task Force is poised to lead the United States into a new environmentally sound and energy-efficient transportation era.

\section{RECENT ACCOMPLISHMENTS OF THE SOUTF}

During the past year the Federal Government contributed one point two million dollars to the Site Operator Users Task Force. These Federal funds were used to purchase state-ofthe-art electric vehicles, purchase infrastructure components, deploy, and demonstrate these technologies. Information on each electric vehicles performance was collected daily and reported monthly to the Department of Energy. On a quarterly basis, each SOUTF member delivered a report to DOE summarizing their vehicles performance and describing the deployment and demonstration activities that were accomplished. From California to Washington, D.C., SOUTF members provided leadership in a variety of electric vehicle activities.

During the same period, Task Force members spent over seven million dollars of private funding to test, evaluate, demonstrate, and deploy electric vehicle and infrastructure technology. Task Force members were involved in specific events that challenged and proved the latest in electric vehicle technology. Task Force members provided government agencies and businesses with information on electric vehicle purchase and operational costs. Government agencies and businesses were even provided short-term loans of electric vehicles so they could evaluate this new technology in their day-to-day applications.

One member of the SOUTF produced the first commercially available, low cost curbside charging system for electric vehicles. This device will allow cities and utilities to provide costeffective opportunity charging, thus extending the limited range of today's battery technology. Other SOUTF members will or are using these chargers to establish an infrastructure system to support commercialized electric vehicles. Another SOUTF member produced a low cost, highly reliable data acquisition system that is being used, no matter where the vehicle is located, to track a particular EV's performance. The information is collected via mobile phone links. The data is invaluable in determining how to build and design more reliable electric vehicles irrespective of the operator's behavior. Another SOUTF member worked with U.S. 
auto manufacturers to develop a certification process for electric vehicle technicians. The major goal of the Task Force remains the same as it has been for the past fifteen years: for the benefit of our environment and the energy security of our Nation, assist a fledgling alternate transportation system into becoming a commercially viable enterprise.

\section{FUTURE SOUTF ACTIVITIES}

On May 10 and 11, at RFK stadium in Washington, D.C., the Potomac Electric Power Company (PEPCO) will host one of the largest showcases of electric vehicle and infrastructure technology. This event is sponsored by the Site Operator Users Task Force together with the Electric Transportation Coalition and the Edison Electric Institute. Key governmental officials will be invited to experience first hand the excitement and potential of electric transportation and infrastructure technology.

During FY'94, the Site Operators Users Task Force plans to sponsor activities in several areas that are critical to the commercialization of electric vehicles. These areas include (1) Electric vehicle test and evaluation, (2) Infrastructure system deployment and evaluation, (3) Public awareness demonstrations, and (4) Fleet Manager Assistance Program, for managers responsible for complying with alternate fueled vehicle purchase mandates.

\section{(1) Vehicle Test and Evaluation}

The SOUTF will purchase increased numbers of prototype electric vehicles for test and evaluation during FY'94. The vehicles will allow the SOUTF to (1) test and evaluate the latest in vehicle and battery technology; (2) provide acceptable numbers of electric vehicles to support infrastructure evaluation efforts; and (3) demonstrate to fleet operators the advantages and potential of electric vehicles.

The Task Force needs financial assistance to begin testing and evaluating new vehicles. Prototype electric vehicles are currently being offered on a limited production basis and are very expensive. For example, the electric version of Chrysler's minivan carries a sticker price of $\$ 120,000$. GM and Ford prototype electric vehicles have similar initial costs. Until automobile manufactures begin large-scale mass production of electric vehicles, the initial cost will remain high. Adding to this initial cost will be the requirement to establish service programs for EVs, install charging facilities, establish rates and cost recovery mechanisms for utilities and cities investing in infrastructure capital-related expenditures, develop national battery procedures, and establish public information programs.

If Original Equipment Manufacturer's (OEM) vehicles are produced in anticipated (limited) quantities, Task Force members will purchase electric vehicles from small domestic manufacturers specializing in EV conversions. Conversion electric vehicles are available for $25 \%$ to $50 \%$ of the cost of OEM supplied vehicles but are still substantially more expensive than conventional internal combustion engine vehicles. Limited testing of these vehicles suggests a potential for their use in niche markets such as urban commuting and light duty fleet vehicle applications. Additional purchases and testing should validate these claims. The SOUTF experience with domestic conversion companies has proven that their products are technically innovative and that they are capable of developing state-of-the-art electric vehicles at a reduced purchase price. With additional purchases from these companies, the SOUTF supports innovation. This domestic innovation may prove to be the key in providing America with a technical lead in commercializing electric vehicles. 
"Infrastructure" is a complex term. It can be as simple as a standard 110 volt extension cord used for recharging electric vehicles or as complex as standardizing a national electrical vehicle energy distribution system. However it is defined, Congress has a major role to play in ensuring that an effective national support system is developed for electric vehicles. The Task Force believes it can help in this task. The SOUTF will devote considerable effort in identifying effective infrastructure products. As they are identified, the SOUTF will deploy those cost-effective devices that will support clectric vehicle use. The Task Force membership will continue its work in developing certification, training, and safety procedures involved with electric vehicle use.

Besides evaluatin $:$ and planning for the physical infrastructure that will be required to support EVs, the Task Force members are actively involved in developing public policy that effectively anticipates the needs of the electric vehicle users. SOUTF members are currently working with state and local governments to provide tax incentives to reduce the cost of owning and operating an electric vehicle. Other incentives, such as low or no-cost downtown parking and removing High Occupancy Vehicles (HOV) restrictions for electric vehicles, are being examined. SOUTF members are working with planning commissions and transportation officials to examine how future transportation systems can use electric vehicle technology.

Public Awareness

A critical aspect of SOUTF activities is keeping the public informed of progress in commercializing electric vehicle technology. Public awareness and acceptance is key to bringing any new technology into the marketplace. Electric vehicle technology use, cost, and application must be understood by the consumer before direct sales will be accomplished. The Task Force membership will sponsor many electric vehicle and infrastructure exhibitions. These exhibitions cover a wide spectrum of audiences including schools, state and local governments, county fairs, and Rotary club meetings. In addition, all SOUTF electric vehicle performance tests, evaluations, and assessments of infrastructure problems and solutions are publicly available. This data is critical to vehicle manufacturers, government agencies, and future electric vehicle owners.

\section{Fleet Operators}

Beginning in FY'94, the Task Force will devote increased attention to supporting fleet operators in purchasing alternate fueled vehicles. Congress has mandated the purchase of increasingly large numbers of alternate fueled vehicles. The SOUTF believes fleet managers should consider electric vehicles in their vehicle acquisition plans. Fleet managers will require technical assistance in evaluating electric vehicle purchase options and they will require financial assistance to reduce the initially higher acquisition costs associated with electric vehicles. The SOUTF membership believes it is uniquely situated and qualified to provide this assistance on a national basis.

\section{CURRENT FUNDING NEEDS OF THE SOUTF}

The Site Operator Users Task Force membership requests this subcommittee's favorable consideration of line item funding for a three point eight million dollar increase, over the FY'93 appropriation of one point two million dollars, for the FY'94 Department of Energy's Site Operator Program. Why is the Site Operator Task Force requesting this increase? From small utilities, such as Orcas Power \& Light, located in the state of Washington, to large 
utilities serving major urban population cunters, such as Southern California Edison and the Los Angeles Department of W'ater and Power serving Southern California, the need for change in our transportation system is clear The National Energy Policy Act mandates the beginning of this change by requiring fleet ope rators to begin purchasing alternate fuel vehicles by 1996. Federal fleets must begin purchasin ; alternate fuel vehicles by 1993 . What is being requested across this Nation is a great technological change. A change that will create new technologies and manufacturing jobs. What is needed is a focus in applying the technology to implement a National Plan.

The SOUTF membership, with its tremendous experience, is the logical place to begin carrying out electric vehicle commercialization and infrastructure deployment. The Task Force in partnership with Congress has fostere $d$ electric vehicle systems. Today, the SOUTF believes that increased funding is absolutely necessary to (1) test prototype electric vehicles in fleet applications and (2) to allow infrasisucture studies, infrastructure demonstrations, and infrastructure deployment to be dene on a national basis. Additional funding would insure that past efforts, progress, and momentum in electric vehicle deployment is maintained. Earlier today the Electric Transportation Coalition (ETC) testified before this subcommittee that the SOUTF is a well-established effort which should remain an "important component of the overall Department of Energy eiectric and hybrid vehicle program" and that "the subcommittee is encouraged to augment funding to this program -- above the level appropriated in FY'93." Although the SOUTF program relies on substantial private sector funding to generate technical clata and operating experience with electric vehicles, the line item funding provided by this subcommittee is the "glue" which will allow our past experience and investments to be fully utilized in meeting Congressional requirements.

\section{CONCLUSION}

For over 100 years the United States has operated its transportation system almost exclusively on a single fuel. During this same period in American history, the benefits of electric transportation were well defined. Because of technological limitations to set up this mode of transportation, the electric vehicle was relegated to a mere curiosity. With the passage of the National Energy Policy Act and recent environmental legislation, the American transportation sector begins a new era. Simultaneously, the technological ability to solve the remaining limitations of electric vehicles looks to be within our grasp. For the past fifteen years the Site Operator Users Task Force has provided the private funding dedicated to producing tangible results in electric vehicle technology development and deployment. As part of the Department of Energy's electric and hybrid vehicle team, the Site Operator Users Task Force looks forward to helping Congress and the DOE meet the transportation guidelines and goals established in the National Energy Policy Act.

This subcommittee's commitment of line item funding for the Department of Energy's Site Operator Program will allow the SOUTF to continue its work. This subcommittee's commitment of funds will ensure the momentum develoned by the SOUTF over the past fifteen years will not be lost at a very cruciai time. The Task Force membership would like to thank this subcommittee for its past and future support. 
APPENDIX C

SOUTF Brochure 

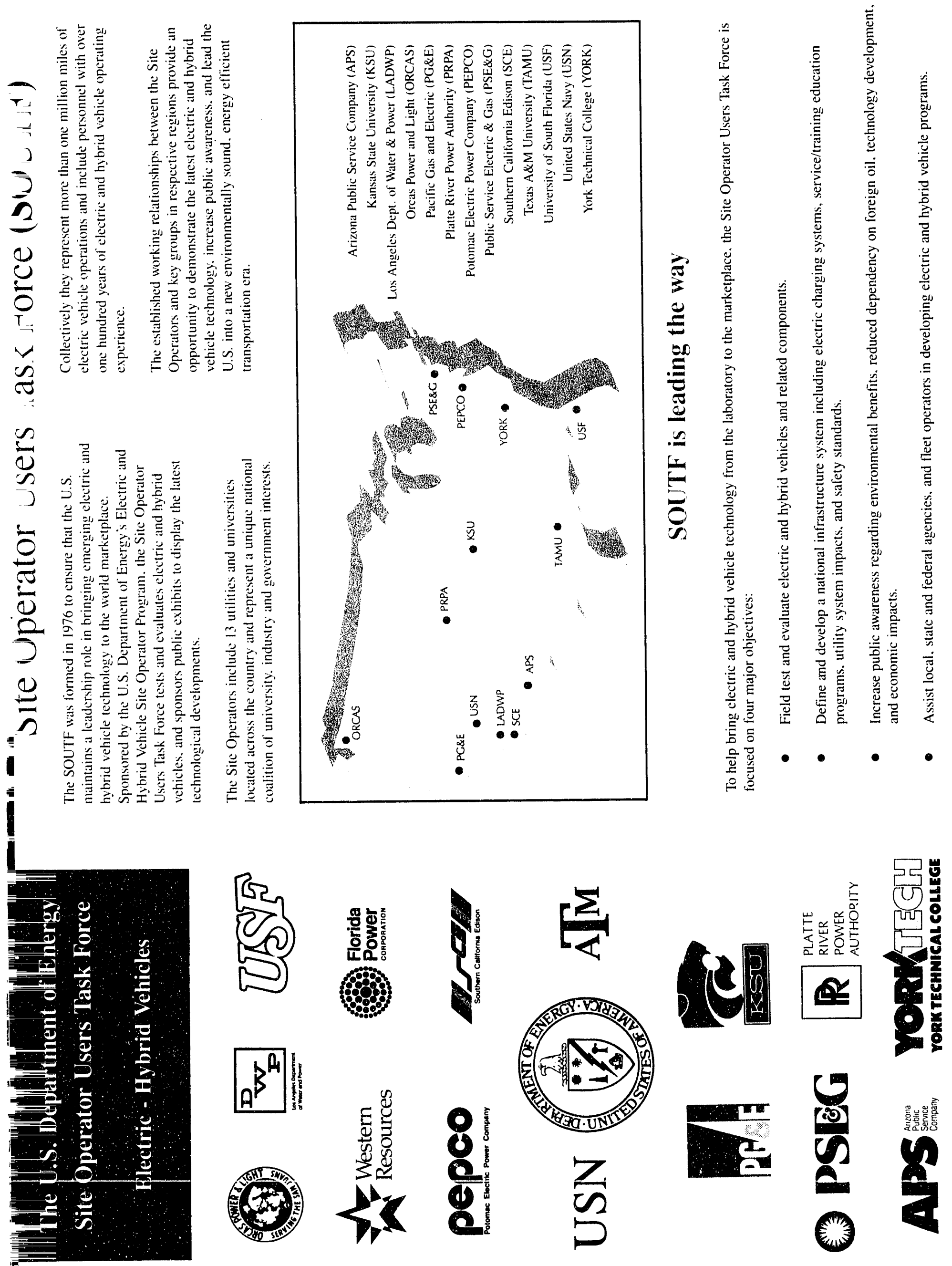

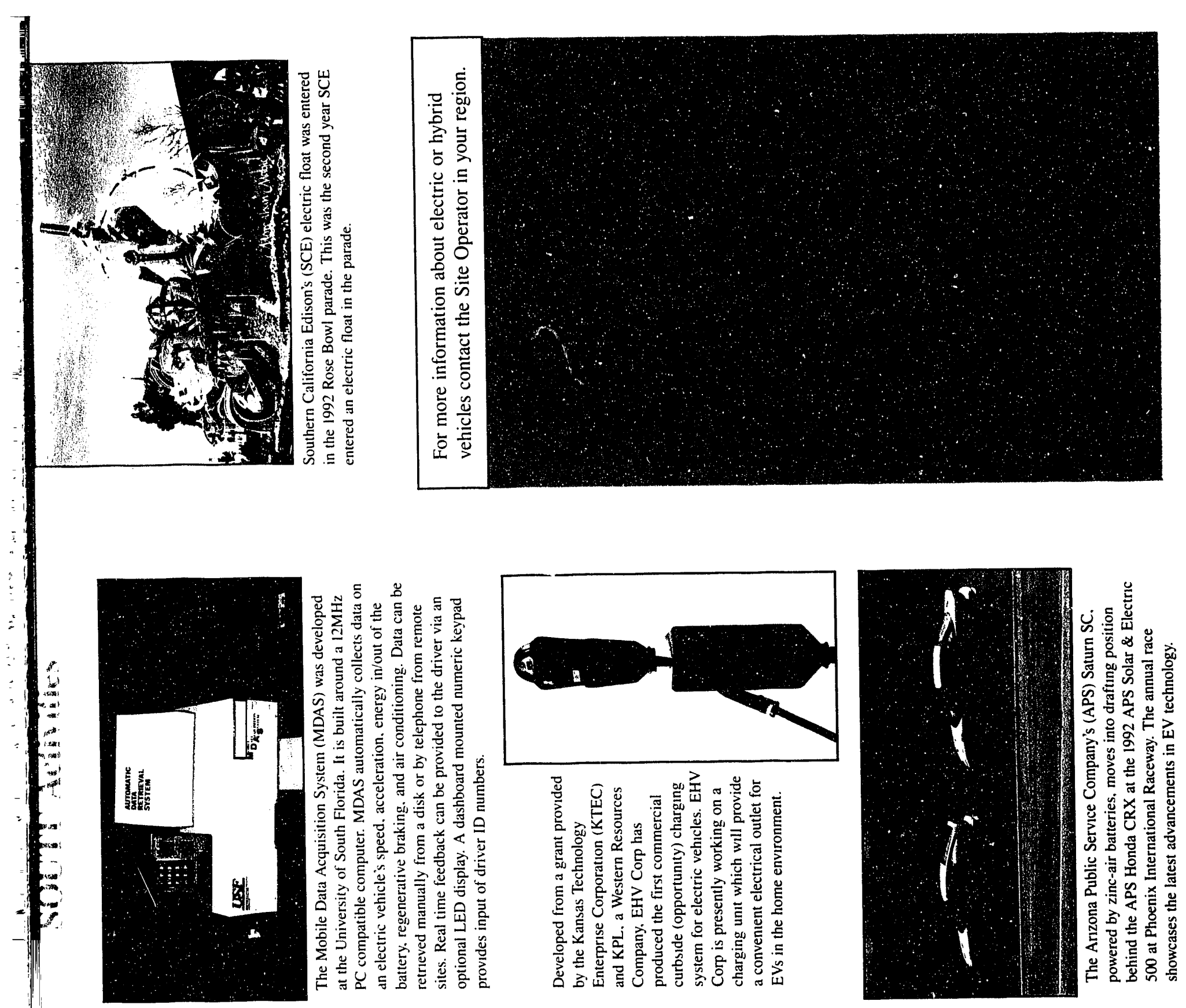


\title{
KANSAS STATE UNIVERSITY
}

\author{
ELECTRIC VEHICLE \\ SITE OPERATOR PROGRAM
}

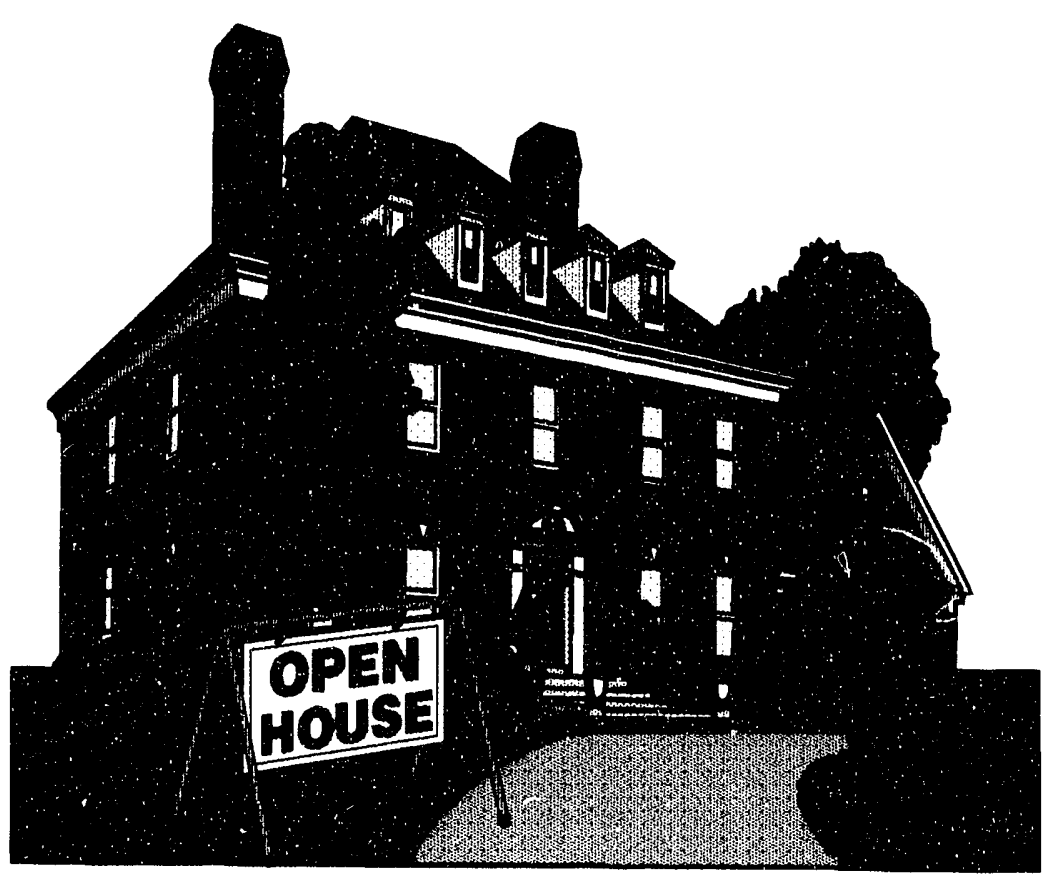

Prepared by:

James R. Hague

\section{Director, Electric/Hybrid Vehicle Program}

Tammy Nissen-Pfrang

Service Technician
Mark A. Maier

Student Assistant
Jarrett A. Thummel

Student fissistant
Jenifer D. Hague

Student Assistant

Kansas State University 219C Soaton Hall Manhattan, KS

Phone: (913) 532 - 5717

Fax: (913) 532 - 5617 

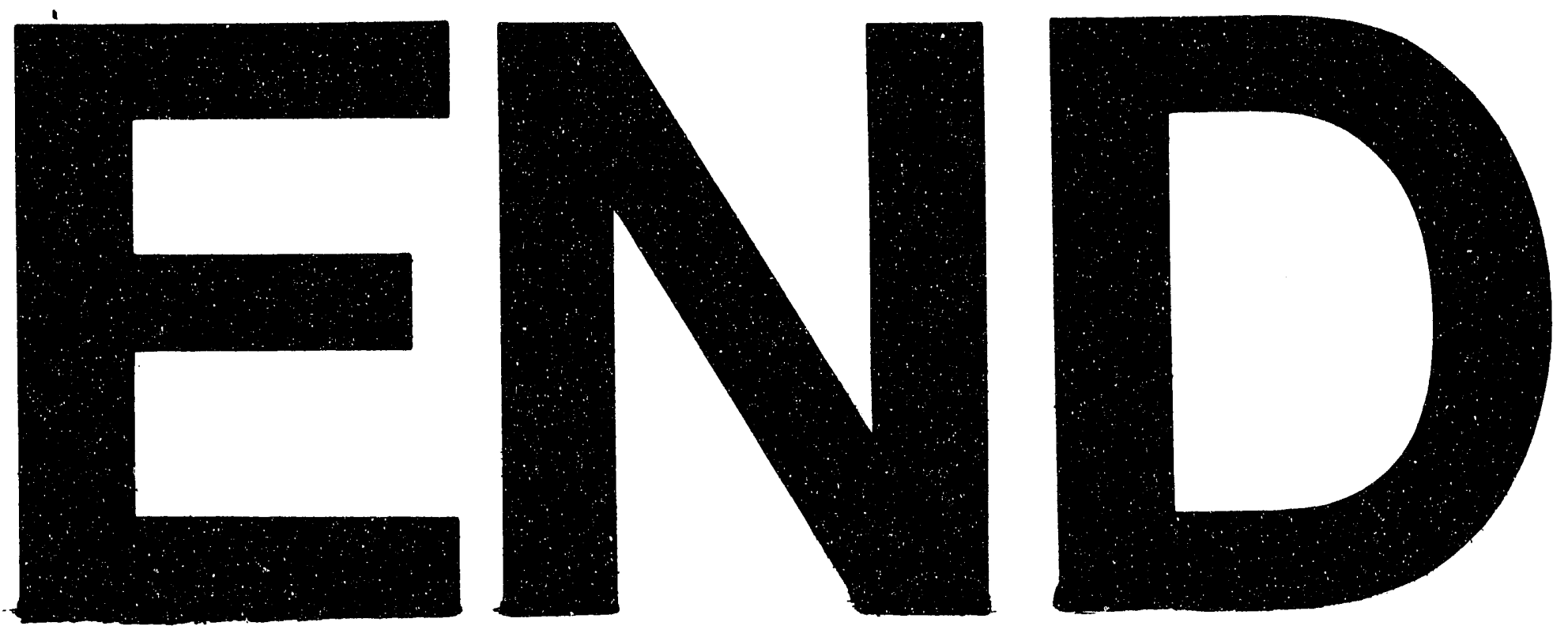

201
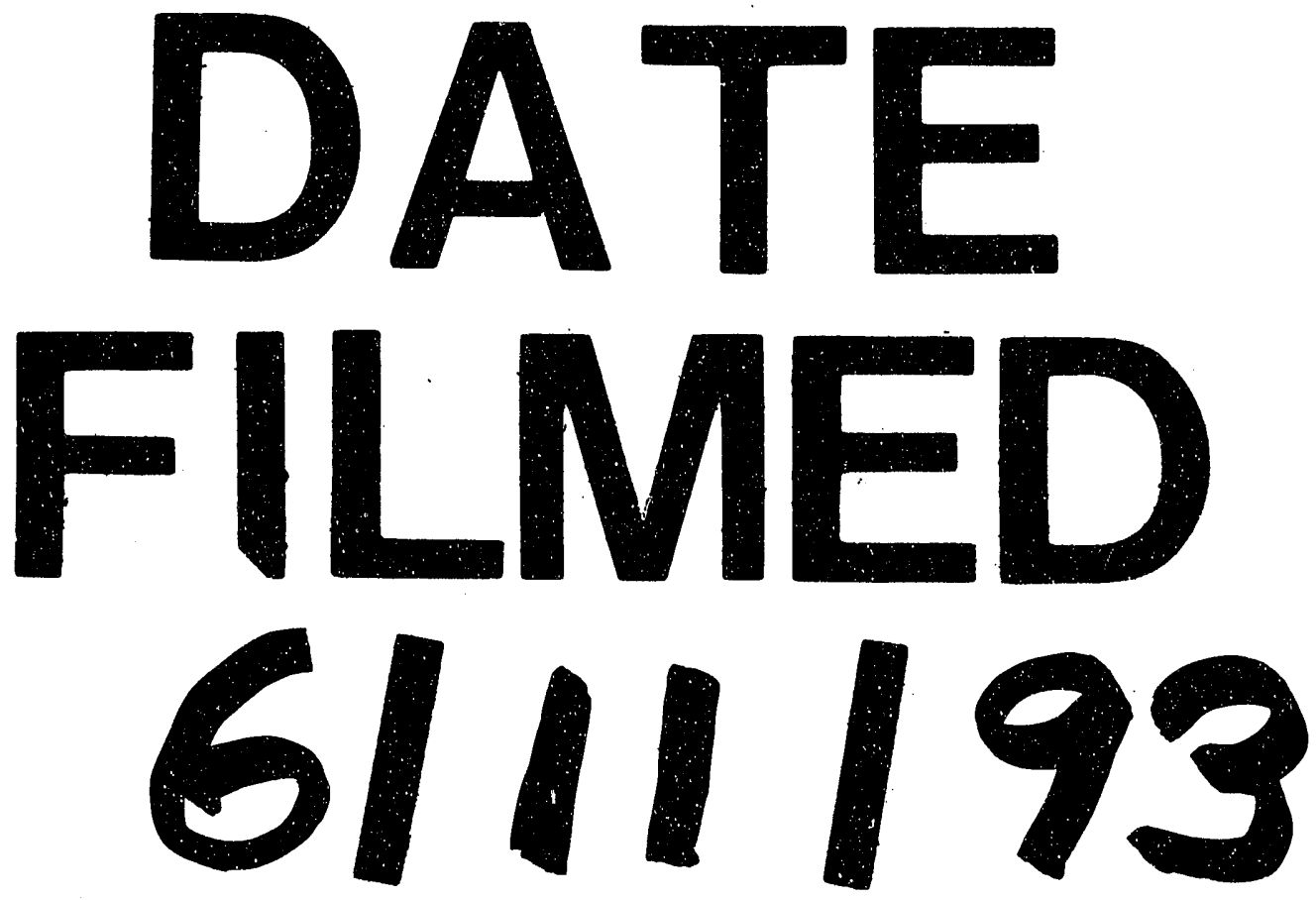
1 